\title{
Description of a new species of the genus Iliotona (Coleoptera: Histeridae) from Guatemala
}

\section{Описание нового вида рода Iliotona (Coleoptera: Histeridae) из Гватемалы}

\author{
Alexander V. Sokolov ${ }^{1}$ \& Alexey K. Tishechkin ${ }^{2}$ \\ Александр В. Соколов ${ }^{1}$, Алексей К. Тишечкин ${ }^{2}$
}

\begin{abstract}
'C.A.S. Aqua Logo, Ostrovityanova St. 30/2-228, 117321 Moscow, Russia. E-mail: margarinotus@yandex.ru.
1 ЗАО «Аква Лого», 117321 Москва, ул. Островитянова, 30/2-228.

${ }^{2}$ c/o Louisiana State Arthropod Museum, Department of Entomology, Louisiana State University, 404 Life Sciences Building, Baton Rouge, LA 70803-1710, USA. E-mail: atishe8@gmail.com.
\end{abstract}

KEY WORDS: Coleptera, Histeridae, Histerinae, new species, Guatemala.

КЛЮЧЕВЫЕ СЛОВА: Coleptera, Histeridae, Histerinae, новый вид, Гватемала.

ABSTRACT. The fourth species of the Central American gunes Iliotona Carnochan, 1917 from Guatemala, I. gilli sp.n., is described and illustrated. An updated key to the species of the genus is included.

РЕЗЮМЕ. Описывается четвёртый вид центральноамериканского рода Iliotona Carnochan, 1917 из Гватемалы - I. gilli sp.n. Приводится дополненный ключ для определения видов рода Iliotona.

\section{Introduction}

The genus Iliotona Carnochan, 1917 is known to be distributed in arid areas of California, Mexico and Cuba and includes three described species [Schaeffer, 1907; Carnochan, 1917; Sokolov, 2005]. All species are reported to be predators of soft bodied insect larvae inside decaying stems of various cacti [Kovarik \& Caterino, 2005; Sokolov, 2005]. Below, we describe a new Iliotona species from Guatemala.

\section{Methods}

Illustrations were prepared with digital camera Canon EOS 40D. Measurements are abbreviated as follows: L - total length of pronotum and elytra, Lp pronotal length, $\mathrm{Wpb}$ - pronotal width across base, Wpmax - maximal pronotal width, We - elytral width across humeri.

\section{Taxonomic part}

Iliotona gilli Sokolov et Tishechkin sp.n. Figs 1-4

MATERIAL. Holotype, $\sigma^{7}$, labeled "GUAT: Zacapa $3 \mathrm{~km}$ W Teculutan 3.VI.1991 B.D.Gill $300 \mathrm{~m} /$ Holotype Iliotona gilli sp. n. des. A. Sokolov and A. Tishechkin." Paratypes, $10^{7}$ and 1 ,, labeled as the holotype except with paratype instead of the holotype designation labels. The holotype is deposited in the Canadian National Collection of Insects, Arachnids and Nematodes, Ottawa; paratypes - in private collections of B. D. Gill, Ottawa, and A.V. Sokolov, Moscow.

DESCRIPTION. Habitus as illustrated (Fig. 1). $\mathrm{L}=10.1$ $\mathrm{mm}$. Black, elongate, almost parallel-sided. Pronotum opaque, elytra smooth. Legs black, club of antennae grey. Head massive, subopaque. Front flattened, with very shallow and sparse punctures, those being much coarser and denser at occipital area. Supraorbital striae well developed, reaching the anterior edge of eyes. Front with two shallow impressions around short, but distinct frontal striae. Punctures in this impressed area somewhat coarser and denser. Mandibles straight, feebly curved near apex, punctured. Basal parts of mandibles dilated, each inner edge with large, acute, transverse basal tooth and very small one proximally. Female paratype has additional median small obtuse tooth.

Pronotum opaque laterally, subopaque on disk, markedly transversal, lateral sides rounded, widest near apical one-third, Wpmax $=8.2 \mathrm{~mm} ; \mathrm{Wpb}=7.9 \mathrm{~mm} ; \mathrm{Lp}=4.6 \mathrm{~mm}$. Median longitudinal stria fine, occupies basal two-thirds of pronotal length. Pronotal disk with punctures as on head. Marginal stria presents in anterior one-third only. Lateral pronotal sides with two striate grooves extending inwardly and anteriorly, one longer and deeper, irregularly interrupted around its midpoint, runs from basal angle, another shorter and shallower - from around midpoint of lateral margin (Fig. 2). Small striate fragment presents near anterior end of basal groove. Apical pronotal angles strongly flattened, with rugose puncturation, without notches apically.

Elytra smooth, as wide as pronotum at base, feebly dilated at humeri, slightly narrowing posteriorly, with sparse and fine punctures, $\mathrm{We}=8.4 \mathrm{~mm}$. Humeral stria extends from humeri posteriorly, abbreviated at apex. First dorsal stria short, basal, about one-fourth of elytral length. Several irregular, short, deep striae present around anterior angles. Second dorsal stria thin, but distinct, long, slightly reduced basally, somewhat fragmented apically, 


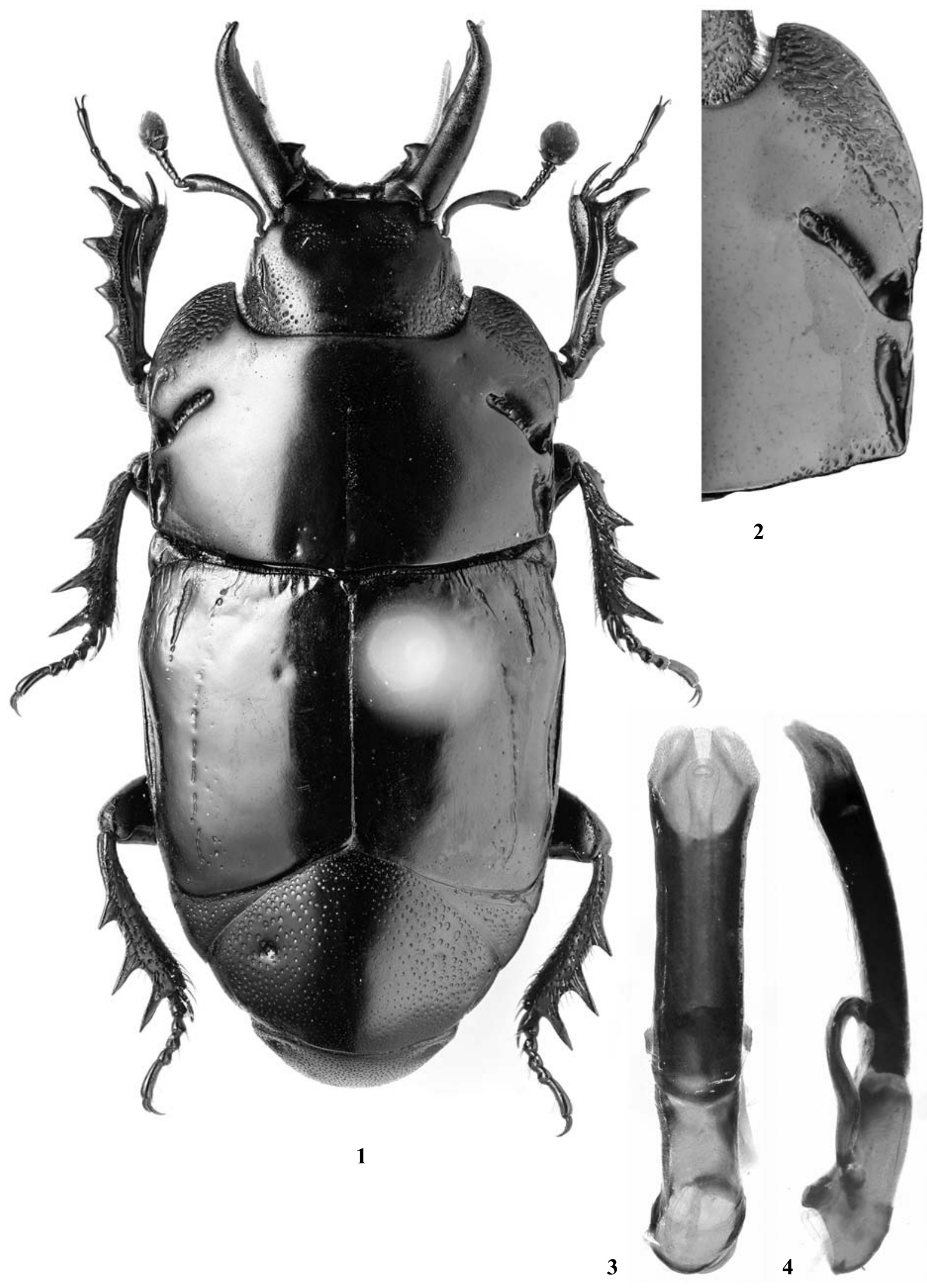

Figs 1 -4. Iliotona gilli sp.n. 1 - habitus; 2 - pronotum; $3-4$ - aedeagus; $1-3$ - dorsal view; 4 - lateral view. Рис. 1-4. Iliotona gilli sp.n. 1 - габитус; 2 - переднеспинка; 3-4 - эдеагус; 1-3 - сверху; 4 - сбоку. 
extreme fragments extend almost to apex. No traces of other dorsal striae present. Outer apical angles opaque as surfaces of head and pronotum. Visible parts of 5-th tergite opaque, with coarse sparse punctures. Propygidium opaque, with a mixture of sparse smaller and larger punctures, being coarser, larger and slightly denser laterally. Pygidium opaque, evenly coarsely and densely punctured (distances between punctures equal to1.0-1.8 punctures diameters), punctures being somewhat shallower towards apex; with circular impression at each side. Mesosternum with marginal stria widely interrupted anteriorly. Discs of mesoand metasternum opaque, their sides rugose, with short thick redish-brown setae. Lateral metasternal striae long, almost reaching metacoxa. Upper surface of meso- and metatibia covered pale reddish setae; setae being longer along outer and inner edges and are arranged into two rows, outer row being situated above teeth.

Sexual dimorphism. In males, body is relatively wider than in females, male heads are more massive, mandibles are longer. Mandibles in females with an extra tooth.

Aedeagus as in illustrated (Figs 3-4).

ETYMOLOGY. The new species is dedicated to its collector, Bruce Gill, in recognition of our long term collaboration and his contributions to tropical beetle collecting.

BIOLOGY. All specimens of I. gilli sp.n. were collected from rotting decaying section of a giant cactus.

COMPARATIVE REMARKS. The new species is similar to I. dorcoides Lewis, which is the only other species of the genus possessing lateral pronotal grooves. I. gilli sp.n. can be distinguished from the latter by the larger size, distinctly opaque pronotum and shape of its grooves. Following key [updated from Sokolov, 2005] can be used to separate the Iliotona species:

\section{Key for Illotona Carnochan, 1917 Species}

1 Pygidium without marginal stria

- Pygidium with sulcate marginal stria along apex I. cacti (J.L. LeConte, 1851)

2 Lateral sides of pronotum with angular projection, without lateral grooves ....... I. markushevae Sokolov, 2005

- Lateral side of pronotum without angular projection, with deep lateral grooves

3 Smaller $(\mathrm{L}=6.4-8.5 \mathrm{~mm})$. Pronotum smooth, its lateral grooves transversally oriented.

I. dorcoides (Lewis, 1888)

- Larger $(\mathrm{L}=10 \mathrm{~mm})$. Pronotum opaque, posterior lateral grooves more or less longitudinal, anterior grooves oblique..... I. gilli sp.n.

ACKNOWLEDGEMENTS. We are grateful to Bruce Gill (Ottawa), who made specimens of this prominent new species available for description. Special thanks are due to Prof. K.V. Makarov (Moscow) for this help with the photos of holotype.

\section{References}

Carnochan F.G. 1917. Hololeptinae of the United States // Annals of the Entomological Society of America. Vol.10. P.367-398.

Kovarik P.W. \& Caterino M.S. 2005. Histeridae Gyllenhal, 1808 // Handbuch of Zoology. Vol.4(38). P.190-222.

Sokolov A.V. 2005. Additions to hister beetles (Coleoptera, Histeridae) fauna of Cuba, with description of new species of genus Iliotona Carnochan, 1917 // Russian Entomological Journal. Vol.14. No.1. P.83-85.

Schaeffer C. 1907. Notes on Histeridae // Entomological News. Vol.18. P.301-306. 